\title{
Argument Linearization in a Three-Dimensional Grammar: A Typological Perspective on Word Order in Polish Sign Language (PJM)
}

\author{
Paweł Rutkowski \& Sylwia Łozińska \\ University of Warsaw, Poland
}

\begin{abstract}
The aim of this paper is to analyze the underlying order of major sentential constituents (the verb and its arguments) in Polish Sign Language (polski język migowy, PJM). Although the issue of sign language sentence structure has been present in the literature for more than 30 years now, no satisfactory account thereof has yet been proposed in the case of PJM. Since visual-spatial communication is not fully linear, the importance (or even presence) of basic word order has gone unnoticed in most early
\end{abstract}

\footnotetext{
Paweł Rutkowski

Section for Sign Linguistics, Faculty of Polish Studies - Wydział Polonistyki, University of Warsaw, ul. Krakowskie Przedmieście 26/28, 00-927 Warszawa, Poland

Phone: +48 225520 869; Email: p.rutkowski@uw.edu.pl

Sylwia Łozińska

Section for Sign Linguistics, Faculty of Polish Studies - Wydział Polonistyki, University of Warsaw, ul. Krakowskie Przedmieście 26/28, 00-927 Warszawa, Poland

Phone: +48 225520 869; Email: s.lozinska@uw.edu.pl
}

Received February 15, 2016; Revised March 10, 2016; Accepted March 15, 2016 
accounts of the linguistic properties of PJM. We analyze the issue of argument linearization on the basis of empirical material extracted from a corpus of PJM which is being compiled at the University of Warsaw, Poland. Although a thorough description has yet to be produced, our data show that PJM does have its own rules of ordering sentential constituents. We conclude that PJM should be classified as an SVO language.

Keywords: sign language, PJM, word order typology, SVO, SOV, sentence structure, corpus

\section{Introduction}

Much of recent linguistic literature on the communication of the Deaf $^{1}$ attempts to investigate to what extent sign languages may be claimed to derive from the same set of (possibly universal) principles that underlies grammars of spoken languages (see, e.g., Sandler \& Lillo-Martin 2006). Undoubtedly, sign languages differ from spoken languages in terms of many aspects of syntax. The key difference relates to the visual-spatial modality: signed constructions may be three-dimensional, rather than strictly linear. However, this observation does not necessarily imply that the universal typology of sentential word orders (e.g., Dryer 2013) is not applicable to the languages of the Deaf. The aim of this paper is to discuss certain word order properties of Polish Sign Language (polski język migowy, usually abbreviated as PJM). The issue of sentence structure has

\footnotetext{
${ }^{1}$ The capitalized spelling of the word Deaf is intended to indicate that we are referring to people who use sign language as their first and preferred means of communication and who feel that they constitute an independent cultural and linguistic community in their country. According to this line of thinking, deafness is not viewed as a disability, but rather as a social identity.
} 
been discussed in the sign language literature since the 1970s (cf. e.g., Fischer 1975, Friedman 1976) but analyses of this aspect of the syntax of PJM have been few and far between. Our work attempts to fill that gap on the basis of data extracted from a newly created corpus of PJM. ${ }^{2}$

\section{What is PJM?}

PJM is a natural language used by the Deaf community in Poland, currently by more than 50,000 signers. PJM is genetically unrelated to Polish and to other spoken languages. This minority language started to evolve around 1817, with the foundation of the first school for the deaf - the Institute for the Deaf-Mute and the Blind in Warsaw.

A vast majority of today's specialists agree that sign languages are functionally equivalent to spoken languages and that the cognitive basis of the manual-gestural communication of the Deaf is not significantly different from that of the spoken language of the hearing (see, e.g., Emmorey 2002). From the perspective of modern Polish linguistics, however, this unanimity is quite recent. Historically, signing was often considered inferior to using spoken

\footnotetext{
2 Parts of this research have been supported by Poland's National Science Center (grant number: 2011/01/M/HS2/03661) and by the Polish Ministry of Science and Higher Education (under the National Programme for the Development of Humanities in 2014-2019, grant number: 0111/NPRH3/H12/82/2014). Preliminary analyses of the data we are discussing in this paper were presented at the 25 th Scandinavian Conference of Linguistics (SCL 25, Háskóli Íslands, Reykjavík, Iceland) and the 11th Theoretical Issues in Sign LanguageResearch Conference (TISLR 11, University College London, London, UK). We are indebted to the audiences of those two conferences for helpful comments and questions. We also acknowledge Daniel J. Sax's help with the preparation of this paper.
} 
Polish. Treated, at best, as a visual aid to lip-reading, PJM was for many decades deprived of the status of a full-fledged natural language. In recent years, this approach has started to change, as is evidenced by a newly passed Polish law on sign language and other means of communication, which, among other measures, grants the Deaf community new rights concerning interpreting services in contacts with public administration. However, PJM is still a heavily understudied language. Rigorous academic research on its grammar and vocabulary only began in the 1990s (cf. Rutkowski \& Sak 2016).

The grammatical structure of PJM is fully independent of that of spoken Polish. This can be illustrated by juxtaposing the following two questions:
(1) Ile
masz lat?
[Polish]
how-many you-have years
'How old are you?'
(2) YOU LIFE HOW-MUCH ${ }^{3}$
'How old are you?'
[PJM]

These two short sentences exemplify the range of differences that may be seen when comparing the two linguistic systems in question: what distinguishes PJM from Polish is not only the visual-gestural modality, but also the choice of lexical elements used in particular

\footnotetext{
3 The most common practice of representing manual signs in print is to substitute them with spoken language labels. We follow this standard in the present paper and gloss PJM signs with English words written in capital letters. Needless to say, this does not imply a one-to-one relation between PJM signs and English words: for instance, the sign glossed as HOW-MUCH is a single simplex lexical item in PJM, while its English equivalent is phrasal. The non-manual tier information is given above the manual glosses.
} 
semantic contexts (e.g., 'years' versus 'life' when asking somebody's age in (1-2)) and, crucially, word order rules (e.g., the initial versus final placement of a question word). Additionally, the issue of three-dimensionality/simultaneity may come into play, for instance the question in (2) is sometimes linearized as in (3):

dominant hand ${ }^{4}$ : non-dominant hand: SQUINT 'How old are you?'

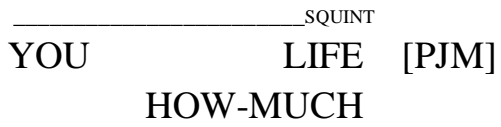

The above structure is a very clear example of how different articulators can be used simultaneously in a sign language utterance. Three linguistic signals are produced at the same time: the lexical signs LIFE and HOW-MUCH and the non-manual squint. It needs to be emphasized that PJM, like other sign languages, is articulated with the signer's whole body, and not only with the hands. The nonmanual articulatory features of visual-spatial languages include body movements, facial expressions, eye gaze, actions of the mouth, nose, brows, and cheeks (cf. Crasborn 2012). Each of these components may play an important role in a PJM utterance. They not only distinguish between different uses of lexical signs but also function as markers of grammatical functions (e.g., in questions, negative sentences or imperatives, cf. Pfau \& Quer 2010).

Any description of the grammar of PJM has to take into account the above-mentioned issues of spatiality (the fact that all signs are produced in the three-dimensional signing space) and simultaneity (signed utterances need not be strictly linear). This, however, does

\footnotetext{
${ }^{4} \mathrm{PJM}$ is not sensitive to handedness, i.e., the dominant hand may be either the right hand (for a right-handed person) or the left hand (for a left-handed person).
} 
not imply that PJM lacks any rules as to how linear sequences of signs should be formed. As will be shown below, typological analyses of major constituent ordering that are based on spoken languages are also applicable to sign languages.

\section{Word Order in Sign Languages}

As noted by Dryer (2011), of the six possible linearizations of arguments with respect to the main verb, only three are commonly found in the world's languages: SOV (subject-object-verb, $41 \%$ of analyzed languages), SVO (subject-verb-object, 35.4\%), and VSO (verb-subject-object, 6.9\%). The remaining three possible orders (OSV, OVS, and VOS) are very rare (from $0.3 \%$ to $1.8 \%$ of analyzed languages; see also Odden's (2003) discussion of the rareness of OSV, OVS, and VOS). In other words, $75 \%$ of the world's languages use SOV or SVO, the next most frequent type is characterized by the absence of a basic word order (13.7\%).

Interestingly, SVO and SOV are also the most frequent basic word orders in sign languages. As pointed out by Perniss, Pfau \& Steinbach (2007: 15), there seems to be no sign language displaying the VSO order. Sign languages analyzed as belonging to the SVO type include American Sign Language, Taiwanese Sign Language, and Brazilian Sign Language, whereas SOV is reported to be the basic word order for, e.g., Austrian Sign Language, German Sign Language, and Japanese Sign Language (Sandler \& Lillo-Martin 2006: 297).

Although a significant number of sign languages have already been described as either SVO or SOV, many researchers point out 
that identifying the underlying order of sentential constituents in a sign language is far from straightforward (see Leeson \& Saeed 2012). Some linguists even argue that sign languages cannot be claimed to have a basic word order, only a most frequent one (Friedman 1976). ${ }^{5}$ Others say that word order is often variable and depends on various factors like the type of the verb used in a given sentence (Fischer 1975, Valli et al. 2011), the aspectual interpretation of the verb (Liddell 1980) or the locative setting (De Weerdt 2008).

As for PJM, the issue of sentential constituent ordering has not yet been properly researched. The earliest known grammatical description of PJM (Hollak \& Jagodziński 1879: 16) views SVO as the only available option. The very few recent analyses that do refer to word order facts often present conflicting generalizations, e.g., Mikulska (2003) states that the most frequent order is SVO, Lausz (2003) supports both options (SVO for short sentences and SOV for longer ones), Tomaszewski (2007) hints at SVO, Tomaszewski \& Rosik (2007) present SOV as the unmarked choice, whilst Tomaszewski (2011) describes SVO as the underlying configuration and SOV as a surface structure derived from the former (although no motivation for this movement operation is specified).

One of the reasons why the above conclusions seem to be contradictory may be the fact that most of the existing analyses of PJM were based on intuitions of individual native signers rather than on representative samples of real language usage. Since PJM, like other sign languages, has no written form, analyzing it on the basis of extensive sets of data was not possible until recent developments in

\footnotetext{
Note that also in the case of research on spoken languages there are analyses arguing against the very idea of the universal typology of word orders. Some authors propose that instead of focusing on the grammatical principles of word order, typological research should mainly pay attention to the rules of ordering given and new information (see, e.g., Ehala 2006).
} 
technologies related to video recording, storage and processing. The study reported in the remaining part of this paper is an attempt to fill the above-mentioned gap in our understanding of how the syntax of PJM works. In order to avoid subjective judgments and stipulations, we have based our analysis on solid empirical data, namely on material excerpted from an extensive corpus of PJM.

\section{Methods}

\subsection{The PJM Corpus Project}

The first-ever large-scale corpus of PJM is being compiled and annotated at the Section for Sign Linguistics of the University of Warsaw (www.plm.uw.edu.pl). The underlying idea behind this project is to gather a collection of video data consisting of elicited and spontaneous sign language utterances, produced by signers who either have deaf parents or have used PJM since early school age. More than 400 hours of video have been collected so far and nearly 100 deaf signers from all over Poland have been recorded. The informants are asked to react to various stimuli that are presented to them during a recording session. These tasks may require, e.g., describing a picture, retelling a story, discussing a video clip, or telling a joke. There is also some room for fully spontaneous conversation. The elicitation materials employed in this project are mostly visual, with as little reference to written Polish as possible. Some of them have been borrowed from other similar projects, in particular from the German Sign Language corpus developed at the University of Hamburg. Figure 1 shows examples of pictures, charts, and videos used when collecting data for the PJM corpus. 
Figure 1. Elicitation Materials in the PJM Corpus Project

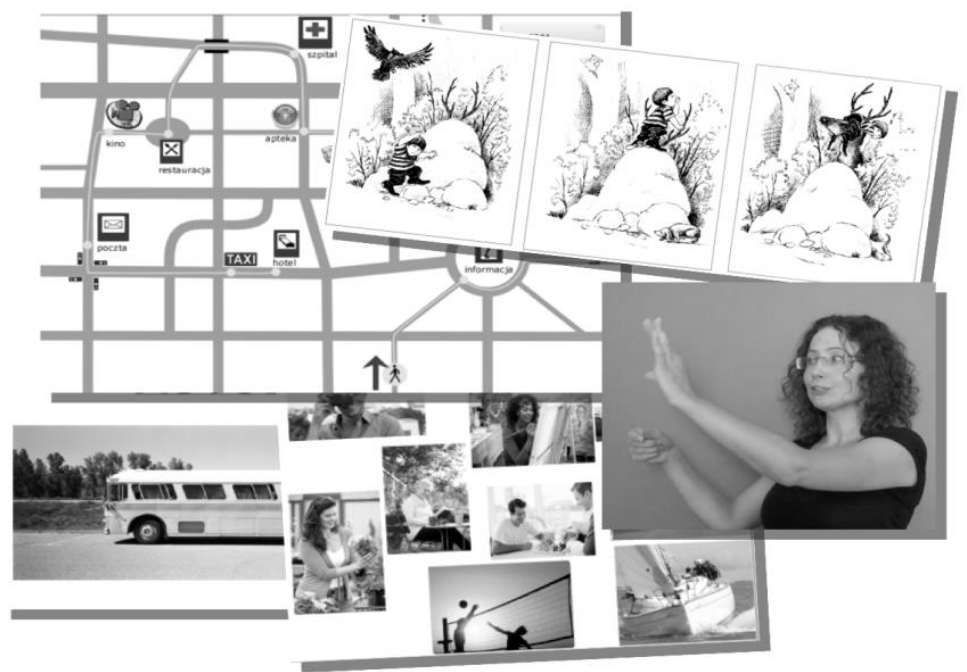

The PJM corpus informants are selected so as to be representative for different groups of age, sex, social background, and education. They are always recorded in pairs, which is assumed to enhance the naturalness of conversations (cf. Rutkowski et al. 2013).

The raw material obtained in the recording sessions is further annotated using the iLex software (a special tool for sign language lexicography and corpus data analysis created at the University of Hamburg, see Hanke \& Storz 2008). The annotators are all Deaf. The annotation workflow includes video pre-processing, sign segmentation and lemmatization, providing the Hamburg Sign Language Notation System (HamNoSys) transcription (see Hanke 2004), clausal segmentation, grammar tagging, and translation into written Polish (Rutkowski, Filipczak \& Kuder 2015). Figure 2 presents a sample of iLex windows, with different columns and fields dedicated to different levels of annotation. 
Figure 2. The iLex Annotation Software

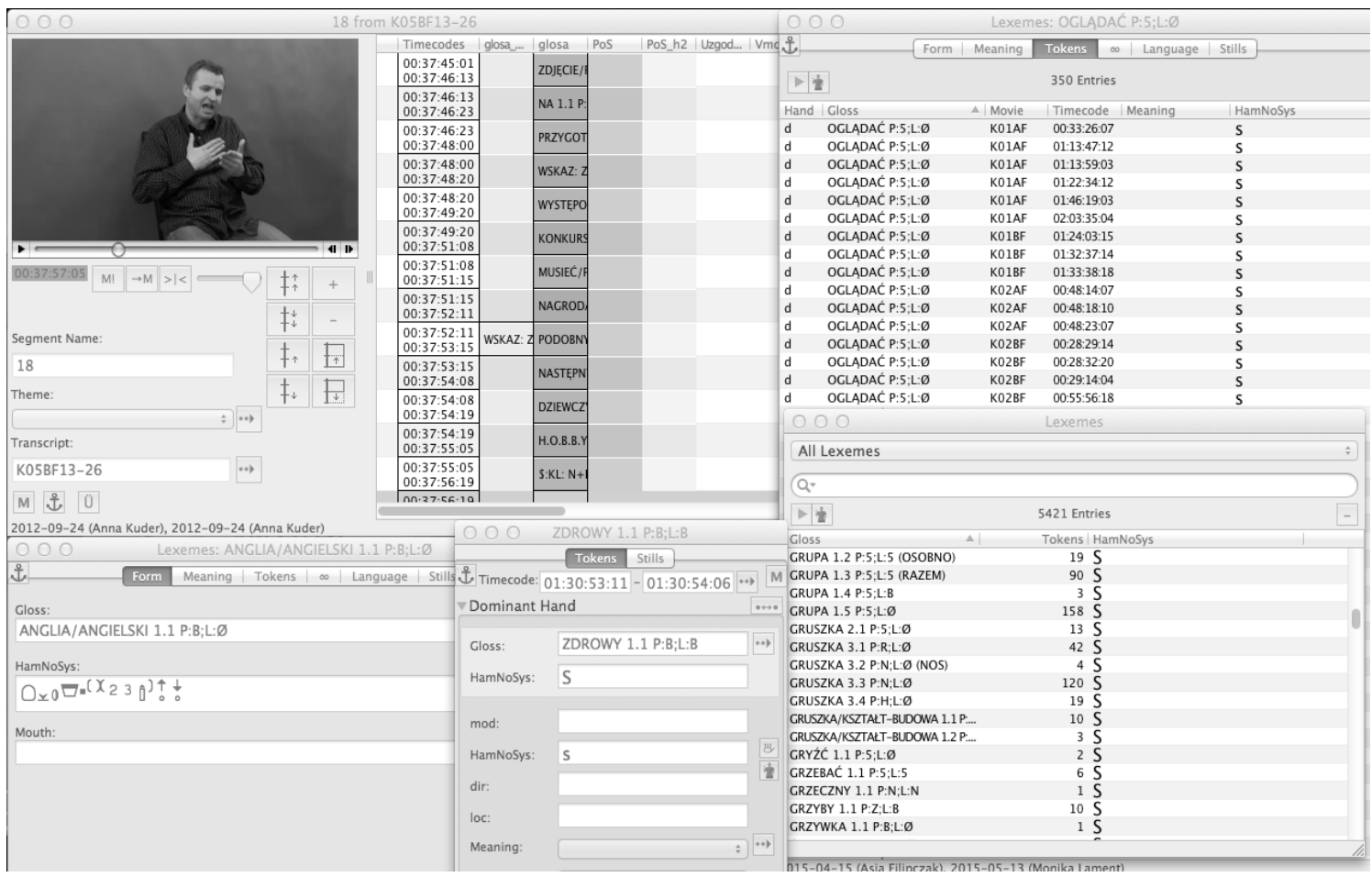


The annotation of PJM corpus is meant to facilitate further detailed investigations into various aspects of the grammar of PJM (see, e.g., Rutkowski et al. 2015). The results of this process have also been used as the empirical basis for proposing the first-ever corpus-based dictionary of that language (see Linde-Usiekniewicz et al. 2014).

\subsection{Analyzed Data}

For the purposes of the present paper, we analyzed six hours of random video material extracted from the PJM corpus - 35 films (representing 21 different elicitation tasks) produced by 15 corpus informants. We carefully inspected this sub-corpus with respect to the structure of the sentences it consisted of. Having delimited 3,000 sentences, we tried to describe them in terms of the universal typology of word orders (as presented by Dryer 2011).

It should be emphasized that dividing signed texts into clauses is not a trivial task (akin to detecting clause boundaries in spoken discourse, see Besacier, Zhou \& Yuqing 2006). The following sample excerpt shows what segmented and glossed corpus data look like':

(4) K04BF15-26 00:34:07:02 00:34:07:07 INDEX-12

K04BF15-26 00:34:07:07 00:34:07:15 SIGN

K04BF15-26 00:34:07:15 00:34:08:04 CANNOT

K04BF15-26 00:34:08:04 00:34:08:10 UNHEALTHY

${ }^{1}$ Each gloss (a word written in capital letters) is preceded by precise timecodes and a combination of letters and numbers serving as a film identifier.

${ }^{2}$ In the literature on sign languages, personal pronouns are usually represented in the following way: INDEX-1 (a pointing sign directed to the signer), INDEX-2 (a pointing sign directed to the addressee), INDEX-3 (a pointing sign directed to another person or object). 
120 Argument Linearization in a Three-Dimensional Grammar : A Typological

K04BF15-26 00:34:08:10 00:34:09:08 EAT

K04BF15-26 00:34:10:11 00:34:11:00 FRENCH-FRIES

K04BF15-26 00:34:11:00 00:34:11:06 STRONG

K04BF15-26 00:34:11:06 00:34:11:14 LIKE

K04BF15-26 00:34:11:14 00:34:12:08 INDEX-1

K04BF15-26 00:34:12:08 00:34:12:18 FRENCH-FRIES

K04BF15-26 00:34:12:18 00:34:13:14 UNHEALTHY

When confronted with such strings of signs, the annotator needs to rely on his/her intuition as to where clausal boundaries should be postulated. In the case of (4), the most obvious delimitation of clauses seems to be as in (5):

(5) K04BF15-26 00:34:07:02 00:34:07:07 INDEX-1

K04BF15-26 00:34:07:07 00:34:07:15 SIGN

K04BF15-26 00:34:07:15 00:34:08:04 CANNOT

K04BF15-26 00:34:08:04 00:34:08:10 UNHEALTHY

K04BF15-26 00:34:08:10 00:34:09:08 EAT

K04BF15-26 00:34:10:11 00:34:11:00 FRENCH-FRIES

K04BF15-26 00:34:11:00 00:34:11:06 STRONG

K04BF15-26 00:34:11:06 00:34:11:14 LIKE

K04BF15-26 00:34:11:14 00:34:12:08 INDEX-1

K04BF15-26 00:34:12:08 00:34:12:18 FRENCH-FRIES

K04BF15-26 00:34:12:18 00:34:13:14 UNHEALTHY

'I signed that one shouldn't eat unhealthily. I really like French fries. French fries are unhealthy.' 
However, it is, in principle, possible to split the above string into different clausal units. Previous sign language studies demonstrated that annotators' intuitions may be supported by a number of more objective diagnostic tests. Although, as noted by Tang \& Lau (2012: 340), sign languages generally lack mandatory morphosyntactic devices marking clause boundaries, Johnston \& Schembri (2006) point out that pauses, blinks, changes in gaze direction, brow movements and changes in head position may all be indicators of where clauses begin and end. Of course, they are not fully grammaticalized and their primary function is pragmatic but they are often quite unambiguous (see also Fenlon 2010, Ormel \& Crasborn 2012). In our study we paid attention to the following signals that may initiate or terminate a phase of phatic interaction:

- manual gestures often associated with sentence/clause boundaries, including:

- the palm-up gesture (Figure 3A, for more details see, e.g., Engberg-Pedersen 2002),

- the waving (attracting attention) gesture (Figure 3B),

- the 'never mind/whatever' gesture (Figure 3C);

Figure 3. Phatic Gestures Attested in the PJM Corpus

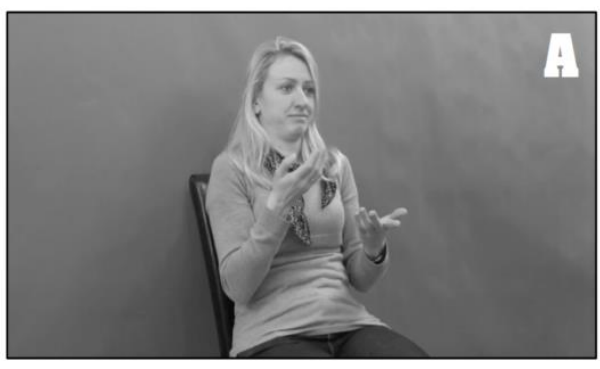


122 Argument Linearization in a Three-Dimensional Grammar : A Typological

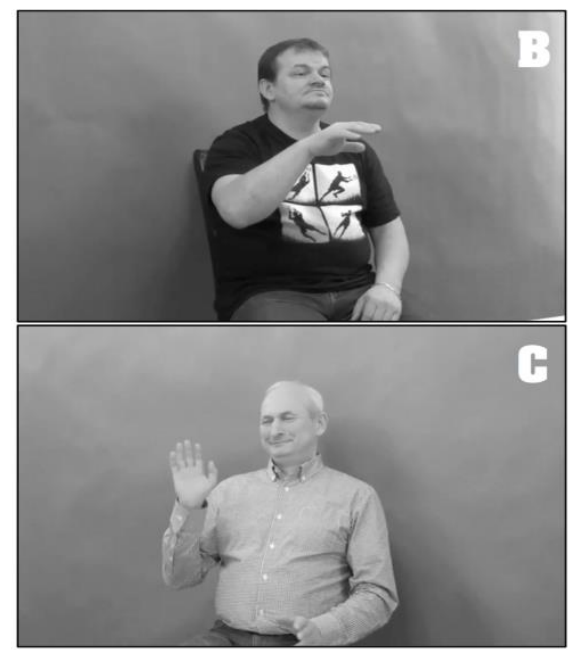

- short and long pauses (with or without hand-drops, Figure 4);

Figure 4. Pauses with Hand-Drops

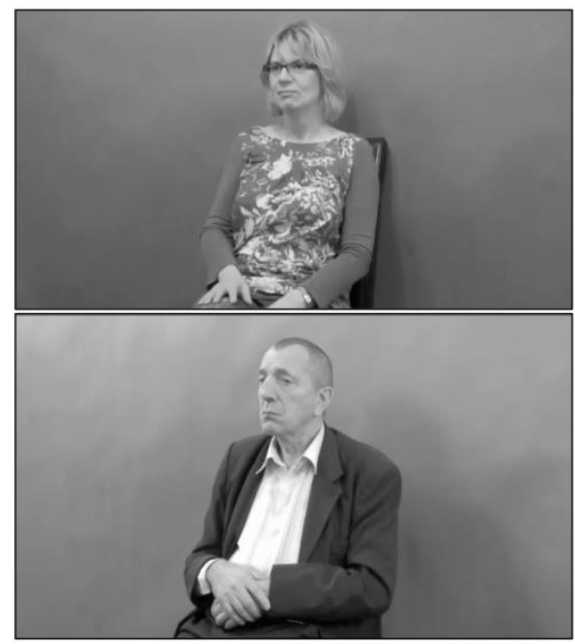


- movements of the body (arms, shoulders, torso), head tilts, and facial signals (nose, brows, eye gaze).

Of course, the most important factor that influenced our decisions concerning the division of corpus material into sentences was the semantic and syntactic coherence of these fragments. The approach in question quite often required subjective judgments and was naturally prone to difficulties related to the conversational character of the inspected data. As the exact message of the signer is always context-dependent, the corpus data annotator is sometimes forced to guess where a given sentence was intended to begin and finish. Therefore, we obviously do not take our observations to be conclusively final and unquestionable. Still, we think they provide a much more reliable approximation of the actual PJM word order pattern than individual signers' intuitions.

\section{Results}

This section summarizes the most important findings of our study. Among the 3,000 sentences that we focused on, we found 300 declarative sentences with two arguments and 1,080 declarative sentences with a single argument. These two groups constituted the basis of the most important word order generalizations that will be discussed below. Figure 5 presents all types of sentences attested in the corpus material, with the relevant percentages. 
Figure 5. Different Types of Sentences in the Analyzed Sample

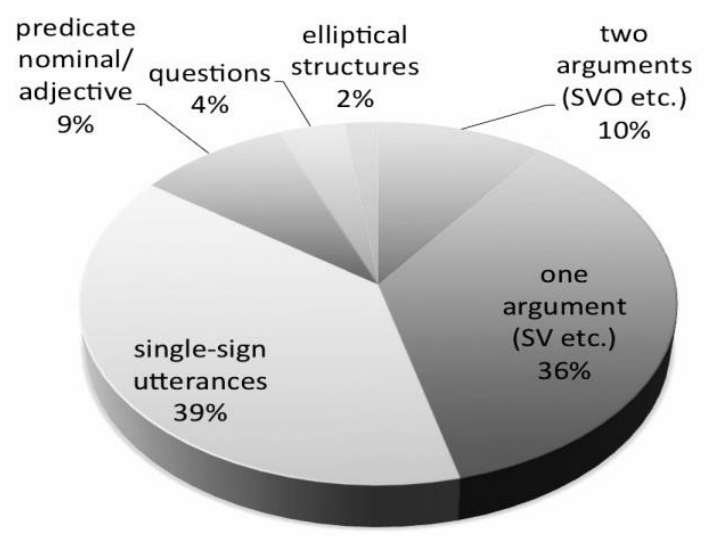

Apart from declarative sentences with at least one argument, the corpus sample included 1,170 sentences that consisted of a single sign. For obvious reasons, they cannot shed any light on the issue of argument ordering tendencies in PJM, so we excluded them from further inspection. Such a large number of single-sign utterances is not surprising considering the conversational character of the data. 270 sentences in the analyzed corpus sample included a predicate nominal or predicate adjective construction (analogous to copular sentences is English). The noun/adjective that is involved in this kind of sentences is not an argument, as its sole function is to indicate a property or identity that is predicated of the subject. There were also 120 questions. We did not consider them indicative of the basic word order of PJM, because, cross-linguistically, questions tend to exhibit unusual constituent ordering (related to the fact that the question word is usually focused).

As for declarative sentences that contain arguments, the corpus data 
we analyzed show very clearly that SVO is the dominant word order for transitive sentences in PJM - see Figure 6.

Figure 6. Results for Sentences with Two Arguments (S \& O)

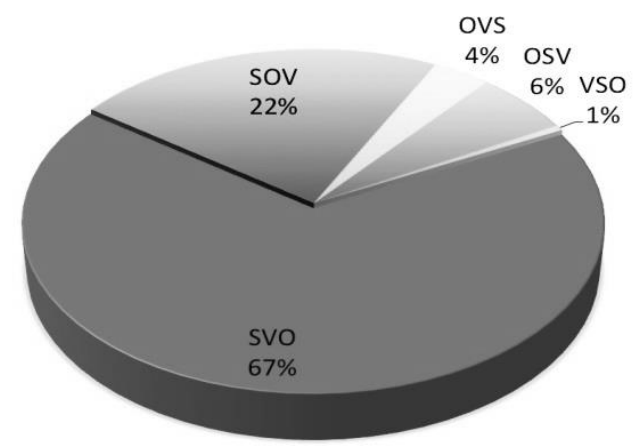

Similarly, SV is the dominant order among declarative sentences with one argument - see Figure 7.

Figure 7. Results for Sentences with One Argument Only

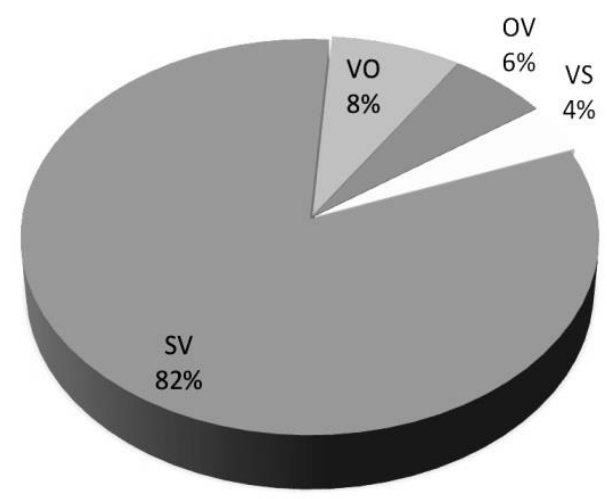


The SV structures are mostly intransitive sentences. The remaining three attested orders are rather infrequent. Many of the VO and OV sentences could in fact be interpreted as pro-drop realizations of the SVO and SOV patterns, respectively, e.g.,:

(6) UNDERSTAND INDEX-2

'I understand you.'

(7) TV WATCH

'I watch TV.'

(8) WATER NEG-WANT

'I don't want water.'

A more detailed inspection of the corpus material underlying this study revealed a number of generalizations that seem to hold across signers. First of all, there is a clear tendency for subjects to be placed sentence-initially. As for structures with two arguments, the verb class (plain vs. non-plain/agreeing/spatial — cf. Padden 1988) tends to play a decisive role. Plain verbs favor SVO, whilst non-plain verbs often trigger SOV. The latter pattern is also found in sentences with classifier predicates (cf. Emmorey 2003). This observation corresponds to the cross-linguistic pattern described in Padden (1988), Kegl (2004), Milković et al. (2006), Hendriks (2008) and Kimmelman (2012), among others. Interestingly, the semantic feature of animacy seems to be an important factor too. When the object is inanimate, the SOV order is sometimes also used in the case of plain verbs (see Morales-López et al. (2011) for similar facts in Spanish Sign Language). The above observations may be summarized as the following list of ordering patterns that prevail in the analyzed data: 
- SV (example (9))

- $\mathrm{SV}_{\text {PLAIN }} \mathrm{O}$ (examples (10-12))

- $\mathrm{SO}_{\text {INANIMATE }} \mathrm{V}_{\text {PLAIN }}$ (example (13))

- $\operatorname{SOV}_{\text {NON-PLAI }}($ examples (14-16))

- $\operatorname{SOV}_{\text {CLassifier }}$ (example (17))

(9) MOUSE SLEEP

'The mouse is sleeping.'

(10) INDEX-1 HAVE HUSBAND DEAF

'I have a deaf husband.'

(11) CAT DISLIKE WATER

'The cat does not like water.'

(12) INDEX-1 CHOOSE TOPIC

'I will choose the topic.'

(13) INDEX-1 APPLE WANT

'I want an apple.'

(14) MRS GRANDMOTHER INDEX-3 KICK

'Grandmother gave him a kick.'

(15) GIRL INDEX-3 3 BOY INDEX- $3_{\mathrm{b}} \mathrm{HELP}_{\mathrm{b}}{ }^{3}$

'The girl helped the boy.'

${ }^{3}$ Different locations in the signing space are indicated with small letters (e.g., distinguishing INDEX-3 $3_{a}$ from INDEX-3 $3_{b}$ means that two different locations were pointed at). Notations like ${ }_{a} H E L P_{b}$ are used for agreeing verbs that are articulated by moving the hand(s) from one location to another. The movement of the sign indicates the subject and the object of the verb. 
128 Argument Linearization in a Three-Dimensional Grammar : A Typological

(16) MAN INDEX-3, WOMAN INDEX-3 LOOK

'The man looked at the woman.'

(17) TALL APPLE CLASSIFIER:SPHERE LOCATION:HEAD $_{\text {SAd }}$

'The tall one had an apple on his head.'

The fact that these generalizations are derived from empirical data lends much credibility to the view that PJM has grammaticalized its own rules of word order.

\section{Conclusions}

The aim of this paper was to analyze the underlying order of sentential constituents in PJM. We examined a random sample of corpus data consisting of 3,000 PJM sentences. The most important results are as follows:

- $39 \%$ of sentences in our sample were one-sign utterances;

- the SVO ordering is much more frequent than SOV;

- SOV tends to be used with non-plain verbs;

- the orders OSV, OVS, VSO and VOS are either unattested or very infrequent;

- for intransitive sentences, $\mathrm{SV}$ is much more frequent than VS.

On the basis of these facts, we conclude that PJM should be considered an SVO (rather than SOV) language. 


\section{References}

Besacier, L., B. Zhou \& G. Yuqing. 2006. Towards Speech Translation of Non Written Languages. In Proceedings of 2006 IEEE ACL Spoken Language Technology Workshop 222-225. Aruba: Institute of Electrical \& Electronics Engineers.

Crasborn, O. 2012. Phonetics, Phonology, and Prosody. In R. Pfau,

M. Steinbach \& B. Woll (eds.), Sign Language. An International Handbook (Handbücher zur Sprach- und Kommunikationswissenschaft / Handbooks of Linguistics and Communication Science - HSK: 37) 4-20. Berlin: De Gruyter Mouton.

De Weerdt, D. 2008. Expressing Existence in Flemish Sign Language. M.A. Thesis. Jyväskylä: University of Jyväskylä.

Dryer, M. 2013. Order of Subject, Object, and Verb. In M. Dryer \& M. Haspelmath (eds.), The World Atlas of Language Structures Online chapter 81. Leipzig: Max Planck Institute for Evolutionary Anthropology.

Ehala, M. 2006. The Word Order of Estonian: Implications to Universal Language. Journal of Universal Language 7.1, 49-89.

Emmorey, K. 2002. Language, Cognition, and the Brain. Insights

From Sign Language Research. Mahwah, NJ: Lawrence Erlbaum Associates. . 2003. Perspectives on Classifier Constructions in Sign Languages. Mahwah, NJ: Lawrence Erlbaum Associates.

Engberg-Pedersen, E. 2002. Gestures in Signing: The Presentation Gesture in Danish Sign Language. In R. Schulmeister \& H. Reinitzer (eds.), Progress in Sign Language Research / Fortschritte in der Gebärdensprachforschung: In Honor of Siegmund Prillwitz / Festschrift für Siegmund Prillwitz 
130 Argument Linearization in a Three-Dimensional Grammar : A Typological

(International Studies on Sign Language and Communication of the Deaf: 40) 143-162. Hamburg: Signum.

Fenlon, J. 2010. Seeing Sentence Boundaries: The Production and Perception of Visual Markers Signalling Boundaries in Signed Languages. Ph.D Dissertation. University College London.

Fischer, S. 1975. Influences on Word Order Change in ASL. In C. Li (ed.), Word Order and Word Order Change 1-25. Austin, TX: University of Texas Press.

Friedman, L. 1976. The Manifestation of Subject, Object, and Topic in American Sign Language. In C. Li (ed.), Subject and Topic 125-148. New York: Academic Press.

Hanke, T. 2004. HamNoSys - Representing Sign Language Data in Language Resources and Language Processing Contexts. In O. Streiter \& C. Vettori (eds.), Proceedings of the Workshop on the Representation and Processing of Sign Languages. 4th International Conference on Language Resources and Evaluation 1-6. Paris: European Language Resources Association.

Hanke, T. \& J. Storz. 2008. iLex - A Database Tool for Integrating Sign Language Corpus Linguistics and Sign Language Lexicography. In O. Crasborn et al. (eds.), Proceedings of the 3rd Workshop on the Representation and Processing of Sign Languages: Construction and Exploitation of Sign Language Corpora 64-67. Paris: European Language Resources Association.

Hendriks, B. 2008. Jordanian Sign Language. Aspects of Grammar from a Cross-Linguistic Perspective. Utrecht: LOT.

Hollak, J. \& T. Jagodziński. 1879. Słownik mimiczny dla głuchoniemych $i$ osób z nimi styczność mających. Warsaw: Instytut Głuchoniemych i Ociemniałych.

Johnston, T. \& A. Schembri. 2006. Identifying Clauses in Signed 
Languages: Applying a Functional Approach. Paper presented at the Deutsche Gesellschaft für Sprachwissenschaft (DGfS) workshop How to Recognise a Sentence When You See One: Methodological and Linguistic Issues in the Creation of Sign Language Corpora 23-24. Bielefeld, Germany.

Kegl, J. 2004. ASL Syntax. Research in Progress and Proposed Research. Sign Language \& Linguistics 7.2, 173-206.

Kimmelman, V. 2012. Word Order in Russian Sign Language. Linguistics in Amsterdam 5.1, 1-56.

Lausz, K. 2003. O linearności i symultaniczności w Polskim Języku Migowym. In M. Świdziński \& T. Gałkowski (eds.), Studia nad kompetencja językowa $i$ komunikacja niestyszacych 99-108. Warszawa: Uniwersytet Warszawski, Wydział Polonistyki, Wydział Psychologii, Polski Komitet Audiofonologii, Instytut Głuchoniemych im. ks. Jakuba Falkowskiego.

Leeson, L. \& J. Saeed. 2012. Word Order. In R. Pfau, M. Steinbach

\& B. Woll (eds.), Sign Language. An International Handbook (Handbücher zur Sprach- und Kommunikationswissenschaft I Handbooks of Linguistics and Communication Science - HSK: 37) 245-265. Berlin: De Gruyter Mouton.

Linde-Usiekniewicz, J. et al. 2014. A Corpus-Based Dictionary of Polish Sign Language (PJM). In A. Abel, C. Vettori \& N. Ralli (eds.), Proceedings of the XVI EURALEX International Congress: The User in Focus 365-376. Bolzano: EURAC Research.

Liddell, S. 1980. American Sign Language Syntax. The Hague: Mouton de Gruyter.

Mikulska, D. 2003. Elementy niemanualne w Polskim Języku Migowym. In M. Świdziński \& T. Gałkowski (eds.), Studia nad kompetencja językowa $i$ komunikacja niestyszacych 79-97. 
132 Argument Linearization in a Three-Dimensional Grammar : A Typological

Warszawa: Uniwersytet Warszawski, Wydział Polonistyki, Wydział Psychologii, Polski Komitet Audiofonologii, Instytut Głuchoniemych im. ks. Jakuba Falkowskiego.

Milković, M., S. Bradarić-Jončić \& R. Wilbur. 2006. Word Order in Croatian Sign Language. Sign Language \& Linguistics 9.1/2, 169-206 (special issue: R. Wilbur (ed.), Investigating Understudied Sign Languages - Croatian SL and Austrian SL, with comparison to American $S L$ ).

Morales-López, E., C. Reigosa-Varela \& N. Bobillo-García. 2012. Word Order and Informative Functions (Topic and Focus) in Spanish Signed Language Utterances. Journal of Pragmatics 44.4, 474-489.

Odden, D. 2003. Languages and Universals. Journal of Universal Language 4, 33-74.

Ormel, E. \& O. Crasborn. 2012. Prosodic Correlates of Sentences in Signed Languages: A Literature Review and Suggestions for New Types of Studies. Sign Language Studies 12.2, 279-315.

Padden, C. 1988. Interaction of Morphology and Syntax in American Sign Language. New York: Garland.

Perniss, P., R. Pfau \& M. Steinbach. 2007. Can't You See the Difference? Sources of Variation in Sign Language Structure. In P. Perniss, R. Pfau \& M. Steinbach (eds.), Visible Variation: Comparative Studies on Sign Language Structure (Trends in Linguistics. Studies and Monographs: 188) 1-34. Berlin: Mouton de Gruyter.

Pfau, R. \& J. Quer. 2010. Nonmanuals: Their Grammatical and Prosodic Roles. In D. Brentari (ed.), Sign Languages (Cambridge Language Surveys) 381-402. Cambridge: Cambridge University Press.

Rutkowski, P. et al. 2013. Jak powstaje korpus polskiego języka 
migowego (PJM)? Polonica XXXIII, 297-308.

Rutkowski, P., J. Filipczak \& A. Kuder. 2015. PJM Corpus Annotation Guidelines. Paper presented at Digging into Signs Workshop: Developing Annotation Standards for Sign Language Corpora. London, UK.

Rutkowski, P. et al. 2015. The Structure of Nominal Constructions in Polish Sign Language (PJM): A Corpus-Based Study. Studies in Polish Linguistics 10.1, 1-15.

Rutkowski, P. \& M. Sak. 2016. Sign Language: Eastern Europe. In G. Gertz \& P. Boudreault (eds.), The SAGE Deaf Studies Encyclopedia Vol. III 796-798. Los Angeles, CA: Sage Publications.

Sandler, W. \& D. Lillo-Martin. 2006. Sign Language and Linguistic Universals. Cambridge: Cambridge University Press.

Tang, G. \& P. Lau. 2012. Coordination and Subordination. In R. Pfau, M. Steinbach \& B. Woll (eds.), Sign Language. An International Handbook (Handbücher zur Sprach- und Kommunikationswissenschaft / Handbooks of Linguistics and Communication Science - HSK: 37) 340-365. Berlin: De Gruyter Mouton.

Tomaszewski, P. 2007. Podstawowe dane lingwistyczne i socjolingwistyczne na temat naturalnego języka migowego. Studia nad Językiem Migowym 2, 5-38. 2011. Lingwistyczny opis struktury polskiego języka migowego. In: I. Kurcz \& H. Okuniewska (eds.), Język jako przedmiot badań psychologicznych. Psycholingwistyka ogólna $i$ neurolingwistyka 184-238. Warszawa: Wydawnictwo SWPS Academica.

Tomaszewski, P. \& P. Rosik. 2007. Sygnały niemanualne a zdania pojedyncze w Polskim Języku Migowym: gramatyka twarzy. 
134 Argument Linearization in a Three-Dimensional Grammar : A Typological

Poradnik Językowy 1, 33-49.

Valli, C. et al. 2011. Linguistics of American Sign Language: An Introduction. Washington DC: Gallaudet University Press. 